\title{
THE EFFECTS OF IMPLICIT AND EXPLICIT CLASSROOM FEEDBACK ON BILINGUAL SPEECH PRODUCTION
}

\section{OS EFEITOS DO FEEDBACK IMPLÍCITO E EXPLÍCITO NA SALA DE AULA NA PRODUÇÃO ORAL BILÍNGUE}

\author{
Janaina Weissheimer ${ }^{1}$ \\ Vaneska Oliveira Caldas ${ }^{2}$
}

\begin{abstract}
Recent research on the role of classroom feedback has pointed out that learning is easier and quicker when students receive detailed feedback that tells them precisely what they have done wrong and what they should have done instead. Our study aimed to investigate how two different types of classroom feedback influence the development of bilingual oral production. Fifty-four English L2 learners were divided into an implicit feedback group and an explicit feedback group. Both groups were exposed to a two-month-hybrid experience for the development of oral production. The implicit group received implicit feedback based on the general content of their oral production. The explicit group received explicit feedback based on grammar, pointing out corrections in relation to the form of their oral production. Through a pre- and post-test, we verified whether the different types of feedback impacted the participants' oral production, in terms of grammatical accuracy, weighted lexical density and fluency. Results show that explicit feedback was more effective in improving learner's L2 grammatical accuracy after the two months of intervention. However, there were no significant differences between the two types of feedback in relation to developing lexical density or fluency over time.
\end{abstract}

KEYWORDS: L2 learning. Bilingual oral production. Explicit and implicit feedback.

RESUMO: Pesquisas recentes sobre o papel do feedback em sala de aula têm evidenciado que a aprendizagem tende a ocorrer de forma mais eficaz e rápida se os alunos receberem feedback que explicite exatamente a causa do erro e como ele pode ser corrigido. Este estudo teve como objetivo investigar o efeito de dois tipos de feedback em sala de aula sobre o desenvolvimento da produção oral bilíngue. Cinquenta e quatro alunos de inglês como L2 foram divididos em um grupo de feedback implícito e um grupo de feedback explícito. Ambos os grupos foram expostos a uma experiência de aprendizagem híbrida de dois meses para o desenvolvimento da produção oral em L2. O grupo implícito recebeu feedback implícito, com base no conteúdo de sua produção oral. O grupo explícito recebeu feedback explícito, baseado na gramática, apontando correções em relação à forma de sua produção oral. Por meio de um pré e pós-teste, verificamos se os diferentes tipos de feedback impactaram na produção oral dos participantes, no que se refere à precisão gramatical, densidade lexical ponderada e fluência. Os resultados mostram que o feedback explícito foi mais eficaz no que tange especificamente o desenvolvimento da precisão gramatical dos aprendizes após os dois meses de intervenção. No entanto, não houve diferenças significativas entre os dois tipos de feedback e o desenvolvimento da densidade lexical ou da fluência durante a intervenção.

PALAVRAS-CHAVE: Aprendizagem de L2. Produção oral bilíngue. Feedback implícito e explícito.

1 Doutora em Inglês (Estudos Linguísticos) pela Universidade Federal de Santa Catarina. ORCID: https://orcid.org/0000-0002-6318-4906. E-mail: janaina.weissheimer@gmail.com.

${ }^{2}$ Doutoranda em Estudos a Linguagem (Linha de pesquisa: Ensino e Aprendizagem de Línguas) na Universidade Federal do Rio Grande do Norte. ORCID: https://orcid.org/0000-0003-0907-5845. E-mail: vaneska_caldas@hotmail.com. 
Volume 15 - Número 2 - ago/dez de 2020

\section{Introduction}

Considering our own practice as English teachers, we have come to the understanding that one of the main reasons that students have for learning a language is being able to communicate orally using it. When we hear that a student has managed, for example, to successfully develop a conversation with a native speaker, or to watch a movie in English without having to rely on subtitles, it gives us a great deal of happiness and pride. However, we are also fully aware that being a proficient L2 speaker is a very difficult goal to be achieved, due to a myriad of aspects that are involved in the L2 learning process, ranging from high cognitive demands to pragmatic appropriateness. As a result, the more we listen to students complain about how hard it is to bridge the gap between what they want to say and what they eventually manage to produce, the more eager we are to look for ways to help them achieve this goal.

In an attempt to help students develop their L2 speech production, we believe that a closer look into the cognitive underpinnings involved in this process is necessary, especially to understand how it can be directly affected by noticing and attention (LEOW, 1997, 2000, 2009; SCHMIDT, 1990, 1995, 2001, 2010). Following this path, Schmidt $(1990,1995)$ proposes The Noticing Theory, which states that, in order to learn, students first need to notice that there is something to be learned. Noticing is not just about internalizing input. It happens mainly when the learner attempts to speak and realizes a gap between what he/she intended to communicate and what, in fact, was said. This process leads the speaker to reflect on his/her interlanguage and to seek new ways to improve oral production. Even though Schmidt's (1995) noticing theory was not conceived based on formal instruction, some researchers (BERGSLEITHNER, 2007; LEOW, 1997, 2000) consider that noticing can also be induced in the classroom. That is, the learner can be led by the teacher to direct his or her attention to formal aspects of the language.

In addition to the importance of consciously registering information, it is also imperative to consider that the processes involved in producing a language are completely different from the ones involved in its comprehension (SWAIN, 1995). That is, it is possible to understand a language without speaking it; but, in order to speak it, it is necessary to understand it first. In this sense, it is only by producing the language that learners leave their comfort zone and move from semantic processing, prevalent in understanding, to syntactic processing, necessary for production. Following this rationale, Swain (1995) proposed the Output Theory, in which, when producing the language, whether speaking or writing it, learners are led to pay attention to the ways in which they intend to express the message and, consequently, to perceive the gaps in their interlanguage, trying to solve the problems that naturally occur (IZUMI; BIGELOW, 2000).

When it comes to assessing learners' speech production, which is the objective of the present study, Skehan (1996) points out three prevalent micro-skill dimensions: accuracy (the ability to avoid grammatical errors), complexity (the ability to use more advanced language) and fluency (the ability to use language in real time). Along the same line, Ellis (2009) claims that a proficient learner is one who, using complex language, is able to fluently perform grammatically correct tasks. Because of our limited attentional resources, when focusing on one of the dimensions in particular, learners invariably limit their capacity towards the other variables (SKEHAN, 1996). The ideal would be to have a balance among all three of them, but, in a communicative situation, speakers tend to prioritize, consciously or not, certain aspects to the detriment of others. This process is called the "trade-off effect" and it is important when trying to explain why learners' oral production may vary, which is the case here.

When helping students notice gaps in their production and, at the same time, deal with the inherent trade-off effects, one may consider that providing them with explicit and implicit feedback may be a powerful strategy to help them move along the L2 proficiency continuum. 
Feedback not only encompasses the mere correction of errors; it also encourages reflection and boosts students' autonomy.

Recently, several researchers have claimed that the quality and accuracy of the feedback students receive determines to a great deal how quickly and successfully they learn (ELLIS, 2015; DEHAENE, 2020). They argue that classroom feedback may play a major role in helping students develop oral production, particularly because, aside from fostering language reflection, giving students feedback also encourages them to identify the weaknesses of their production, and, therefore, to continue producing. Feedback, due to its dialogical character, can be an important ally in the learning process, since it represents a way to engage and to empower learners. In the same direction, feedback helps students to test their hypotheses, in addition to guiding learners in modifying or reprocessing their output (SWAIN, 1993; 1995).

Swain $(1993 ; 1995)$ observed that feedback plays an important role in testing hypotheses about structure and meaning, since, in general, feedback is necessary to confirm the hypotheses that learners generate. In addition, feedback can guide learners in modifying or reprocessing their output (SWAIN, 1993; 1995). However, the question whether explicit or implicit feedback would yield better results in the classroom is still inconclusive. In this sense, Ellis (1994) states that explicit corrective feedback is an effective way to promote learning, because when students receive explicit feedback about their communication efforts, acquisition is more likely to occur. Explicit feedback not only makes the problem clearer for the student, but also contributes to the internalization of the rule. While it is now indisputable that feedback needs to be clear and focused on the learners' goals, one question that still remains is whether feedback should focus explicitly on inaccuracies in speech production, or it should alternatively focus more holistically on the content of the message, rather than its form.

In a study developed by Ellis, Loewen and Erlam (2006), the authors aimed to verify the effects of two types of corrective feedback - explicit and implicit - on the acquisition of past simple tense in the English language. The study is conducted with two experimental groups, each receiving a type of feedback - reformulations, in the case of implicit feedback, and metalinguistic explanation, in the case of explicit feedback. There is also a control group, which does not receive feedback. Results suggest that explicit feedback is more effective than the implicit one, due to the high level of consciousness that such feedback brings to the learners, by the comparison between the target language and their own production, thereby contributing to the learning process.

Taking all this into consideration, we set off to verify which type of feedback - explicit and implicit - may impact learners' L2 speech production to a greater extent. Based on Ellis (1994) and Ellis, Loewen and Erlam (2006), who claim that explicit feedback represents a major advantage in the development of L2 oral production, we hypothesized that learners would benefit more from explicit grammar-based feedback than from implicit content-based feedback, because the former contains direct reference to their grammatical inaccuracies, while the latter focuses exclusively on the content of the message. In the end, we intend to shed some light into the following research question: What is the impact of implicit and explicit feedback on the development of L2 speech production, in terms of grammatical accuracy, lexical density and fluency? What follows is the description of the methodological design of our study.

\section{Methods}

We designed a naturalistic classroom experiment to verify how two types of feedback implicit and explicit - would impact L2 learners' speech production. In order to reach such goal, 54 English as L2 learners participated in the study, who were randomly divided into an explicit feedback group (29 students, 21 women, mean age 27.3) and an implicit feedback group (25 students, 16 women, mean age 28.6). All participants were exposed to a hybrid experience, that 
is, for approximately 2 months, they received asynchronous feedback on WhatsApp in addition to attending regular classes ( $\sim 3$ hours per week). They were asked to record short audios. The implicit feedback group (control) received, after each oral task, feedback based on the content of the message, solely related to the meaning of the message (e.g. I'm so glad you enjoyed your weekend in Pipa). The explicit feedback group (experimental), in its turn, received feedback based on grammar and pronunciation, pointing out corrections in relation to the form of the message (e.g. When you talk about a past situation, you must use 'went' instead of 'go'). Through a pre and a post-test, we checked which type of feedback (implicit or explicit) would be the most effective one over the two months of intervention.

In order to decide which types of feedback we would provide in this study, two main aspects were considered: on the one hand, by choosing to give feedback based on the content of the message, one may argue that, by not emphasizing form, students would feel more engaged to develop their speaking, since they would experience less pressure to produce the language and, therefore, would focus primarily on communication. On the other hand, by explicit acknowledging students' errors, one may advocate that speech production would develop more thoroughly. In order to better understand both types of feedback, we bring the following examples.

\section{PARTICIPANT OF EXPLICIT FEEDBACK GROUP}

I love to trip / My favorite trip is to Bahia / I tripped to Bahia with my friends / We stayed in Bahia for one week / We stayed on a hotel / We took very pictures / We ate differents foods / We danced and we drinked a lot / We slept until ten o 'clock / We went do the beach / We bought presents / We went in plane

Explicit Feedback: “Oi! Eu de novo, kkk! Gostei muito do seu áudio, ficou ótimo! Só tem uns detalhes que eu queria apontar, pra você pensar a respeito, certo? Por exemplo, "trip" e "travel" são diferentes. O primeiro é substantivo, viagem, e o segundo é verbo, viajar. Outra coisa: a gente não usa "very" quando tem um substantivo depois. E lembra que a gente viu que adjetivos em inglês nunca vão pro plural? E que, antes de meios de transporte, a gente usa "by"? Pra fechar, "drink" é um verbo irregular, tá? Obrigada pelo seu speaking, querida! A gente se vê em sala! Até lá!" ${ }^{3}$

\section{PARTICIPANT OF EXPLICIT FEEDBACK GROUP}

I want to travel to Canada / I want to live in Canada / I want to live in Toronto / I have a friend live in Toronto / Toronto is a beautiful city / is cold / I visit my friend in December / I take pictures / I stay in the apartment of my friend / I think Canada is a wonderful country / I have a job in Toronto

Implicit Feedback: "Oi! Olha eu aqui de novo, kkk! Seu áudio ficou show, gostei muito! Eu também tem muita vontade de viajar pro Canadá, mas só pra visitar! Pra morar não dá, não! É muito frio! E você foi visitar seu amigo em dezembro?! Deve ter congelado, né? Eu também tenho amigos que moram em Toronto. Estou planejando ir

\footnotetext{
${ }^{3}$ Explicit feedback: "Hi! Me again, hahaha! I really liked your audio, it's great! There are only a few details I'd like to point out, so that you can reflect on them, ok? For example, "trip" and "travel" are different. The first is a noun; the second, a verb. Another thing: we don't use "very" when we have a noun afterwards. And remember we studied that adjectives in English never have a plural form? And that we use "by" before ways of transportation? Finally, "drink" is an irregular verb, ok? Thank you for your speaking, dear! See you in class! Cheers! (translated by the authors).
} 
Volume 15 - Número 2 - ago/dez de 2020

visitá-los. Eles disseram que lá é fácil de arrumar emprego, que tem muitas opções. Vou fazer igual a você, vou ficar no apartamento deles. Mas vou planejar a viagem pra um mês mais quentinho, kkk! Obrigada pelo seu speaking! Vejo você na sala! Até mais!" 4

The first feedback focuses on providing explicit linguistic explanation; the second, on the content of the message itself, trying to reproduce what an actual conversation would be like.

\subsection{Context of participants}

Data collection happened at two different points in time, between May and July 2017 and between September and November 2017 in a private language school in the city of Natal, $\mathrm{RN}$. In this institution, classes can take place twice a week $(1 \mathrm{~h} 30$, each) or once a week $(2 \mathrm{~h} 45)$. The 54 participants were from seven different classes, three in the first semester of 2017 and four in the second semester.

\subsection{Data collection procedures and instruments}

Students were randomly divided into two groups, control (receiving implicit feedback) and experimental (receiving explicit feedback). Both groups were submitted to a pre and posttest, in which their L2 speech production was evaluated. The pre-test consisted of an adaptation of a free sample of the Key English Test (KET), a proficiency test applied by the University of Cambridge. The purpose of using this validated test was to more reliably assess learners' grammatical accuracy, weighted lexical density and fluency, before and after performing oral tasks through WhatsApp. The test used in this research consisted of describing an image for at least one minute. Students were given a minute to plan their speech before they were recorded on a cell phone. As for the post-test, we performed the same procedure as the pre-test, that is, both groups, experimental and control, had to describe an image, different from the one used in the pre-test, so that we could reassess their accuracy, weighted lexical density and fluency after the two-month intervention.

The use of technology in L2 learning allows an asynchronous exchange of information, which may lead to a series of benefits to the learners: it contributes to increase students' autonomy, it encourages students to explore the language, it allows students time to reflect on the feedback they receive, and so on (COSTA, 2013; BOUHNIK; DESHEN, 2014; BOTTENTUIT; ALBUQUERQUE; COUTINHO, 2016). In that context, WhatsApp, an instant free message app for Smartphones, gains more and more space every day. Additionally, nowadays communication between teachers and students through WhatsApp is quite common and works for several different purposes, such as to solve doubts, to receive feedback, to fill in possible gaps from the presential meetings and to encourage students to feel more confident to share their productions. These reasons justify our choice of this user-friendly technology to assign the tasks and to give feedback about them.

In this study, between the pre and the post-test both groups (implicit and explicit feedback) were asked to record four small audios about pre-established themes. Taking in consideration that our study is ecological; that is, it focuses primarily on maximize students'

\footnotetext{
${ }^{4}$ Implicit feedback: Hi! Me again, hahaha! Your audio was great, I liked it a lot! I also really want to travel to Canada, but only to visit it! To live there? No way! It's too cold! And you went to visit your friend in December?! It must have been freezing, right? I also have many friends who live in Toronto. I've been thinking about visiting them. They said it's easy to find a job there, that there are several possibilities. I'm planning on doing the same as you did, I will stay at their apartment. But I'm going to plan my trip to a warmer month, hahaha! Thank you for your speaking! See you in class! Cheers! (translated by the authors).
} 
learning in a naturalistic setting, we understand that - differently from laboratory studies - it is even more challenging to control all variables in the classroom. Therefore, students were left free to record the audios for as many times as they pleased before sending them to the teacher (one of the researchers), as well as had the freedom to choose where to record them.

Even though being able to record the audios freely may have impacted the development of students' oral production (regardless of type of feedback they received), we understand that, for the purpose of this specific study, by allowing students to do so we helped enhance their spontaneity and confidence, as well as the likelihood to notice their mistakes.

The themes for the recordings were always related to the ones seen in the pedagogical material during classes, such as introductions, food preferences, describing a trip and advising a friend. After listening to each speech production sample, the researchers provided feedback (based on the group students were placed in, implicit or explicit) in Brazilian Portuguese, the students' native language.

We chose to provide feedback in Brazilian Portuguese aiming to encourage students' participation and to direct their focus to the feedback itself, instead of risking overwhelming them with a new task (understanding the feedback in the target language they are learning). The feedback, as well as the given tasks, were also provided orally, in a single message. Between sending the audio and receiving feedback from the teacher, the average interval was five days. Students were advised to listen to the audio they had produced again, but it was not mandatory. Also, students could answer the feedback sent by the teacher with additional questions or concerns, if they wished to.

Rather than providing feedback to all types of errors produced by the students, we chose to emphasize the ones which were closest to the contents students had already studied or were studying in the current semester. In doing so, our goal was to help students internalize the language, hence contributing to improve their oral production. Also, we felt it was important to keep the feedback short, so that students did not feel discouraged to perform the subsequent tasks. To illustrate, we present the following pre and post test samples of one of the participants of the experimental group (which received explicit feedback), accompanied by the audio transcription of one of the tasks performed by him and the respective feedback.

EXP 26 PRE TEST I can see a family / I can see peoples two mans, two womans and two childrens / They are in a restaurant / They are eating / I can see a table / On the table I can see glasses and plates / The man and the woman are helping the kids / They are eating pizza because they like. They eat pizza in the restaurant / They go restaurant on weekends

EXP 26 TASK 1 I am from Pau dos Ferros but I live in Natal / I always travel to Pau dos Ferros / I am a teacher / I teacher childrens / I work in three schools / I have very students / I correct very exams / at night I go to gym / at weekends I go to beach / I watch Netflix / I sleep / I wake up at five o'clock / I go sleep at midnight

EXP 26 FEEDBACK TASK 1 Olá! Gostei muito do seu áudio! Tem só alguns detalhes pra você dar uma olhadinha, tá? Por exemplo, "teacher" é o substantivo "professor". Quando você quiser o verbo “ensinar", é "teach", sem o "er", lembra? Lembra também que a gente viu que alguns plurais em inglês são irregulars, tipo "childchildren", "person-people", "tooth-teeth"... Outra coisinha: não pode usar "very" com substantivos, não é? E, quando tem dois verbos juntos, a gente usa "to" pra separá-los, "I go to sleep". Muito obrigada pelo seu speaking e amanhã! 
Volume 15 - Número 2 - ago/dez de 2020

EXP 26 POST TEST I talk about picture / The picture show people in the kitchen / Have four people / a mother, a father, two children / They are cook / They are cook lunch / They like cook noodles / They are not fat / They can eat noodles / They are in the kitchen / They are a man, a woman, a boy and a girl.

As we can see by the example (emphasis in bold), besides not addressing all errors, we always made sure to use a light tone when providing feedback, especially considering the naturalistic approach of our study. Also, by comparing the type of text produced in the pre and post-test (description of an image) and the type of text produced in the oral production tasks, for which feedback was given (audios on pre-established topics), one may argue that the type of error may be of a different nature from which could occur in an image description task, used in the pre and post-test. In the given example, we notice that the participant, both in the pre-test and in the task, had difficulties in relation to the use of irregular plurals, such as "children" instead of "chidrens" or "people" in place of "peoples". After the feedback, in the post-test, this problem seems to have been overcome, which leads us to infer that the explicit feedback may have contributed to the participant internalizing the information about irregular plurals.

\subsection{Data analysis procedures}

The pre and post-test oral productions were transcribed, and speech measures were calculated based on Weissheimer (2007). Fluency scores were calculated dividing the number of words spoken by the time per minute; grammatical accuracy was determined by the amount of grammatical errors in every 100 words; and the weighted lexical density scores were reached by dividing the number of lexical items by the total words with lexical and grammatical properties produced.

The data were analyzed using SPSS (Statistical Package for the Social Sciences), using paired-sampled T-tests, since the scores displayed a normal distribution according to the Shapiro-Wilk test. In order to check whether there were any statistically significant differences between the scores of the two groups, we set the $p$ value at 0.05 .

\section{Results and discussion}

To reiterate, the aim of this study was to investigate the impact of implicit and explicit feedback on L2 oral production, in terms of grammatical accuracy, weighted lexical density and fluency. In order to address our research question, we formulated the following hypothesis: learners will benefit to a greater extent from explicit feedback than from implicit feedback, because the former contains direct reference to their grammatical inaccuracies, while the latter focuses exclusively on message content. Our hypothesis is based on Ellis (1994) and Ellis, Loewen and Erlam (2006), whose research results reported that explicit corrective feedback represents a major advantage in the development of oral production.

Therefore, from this point on, we discuss our findings, readdressing our hypothesis and establishing connections between our results and the ideas expressed by the researchers we have mentioned in the Introduction.

In regard to grammatical accuracy, results displayed in Table 1 and Graph 1 show that there was a decrease in the number of errors made by both groups, the implicit (IMPpostaccuracy: 12.14, IMPpreaccuracy: 13.04) and the explicit one (EXPpostaccuracy: 9.30, EXPpreaccuracy: 11.59), with a medium effect size for the explicit feedback group (Cohen's $d=0,52$ ), and a small effect size for the implicit feedback group (Cohen's $d=0,21$ ). 
Volume 15 - Número 2 - ago/dez de 2020

TABLE 1 - Descriptive Statistics of implicit and explicit accuracy scores

\begin{tabular}{|l|l|l|l|l|l|l|}
\hline & N & Minimum & Maximum & Mean & $\begin{array}{l}\text { Std. } \\
\text { Deviation }\end{array}$ & $\begin{array}{l}\text { Cohen's } \\
d\end{array}$ \\
\hline EXPpreaccuracy & 29 & 4,00 & 24,56 & $\mathbf{1 1 , 5 9}$ & 5,43 & $\mathbf{0 , 5 2}$ \\
EXPpostaccuracy & 29 & 4,55 & 16,00 & $\mathbf{9 , 3 0}$ & 3,13 & \\
IMPpreaccuracy & 25 & 4,61 & 19,61 & $\mathbf{1 3 , 0 4}$ & 3,70 & 0,21 \\
IMPpostaccuracy & 25 & 4,34 & 26,22 & $\mathbf{1 2 , 1 4}$ & 4,54 & \\
\hline
\end{tabular}

In addition, still taking into consideration the descriptive statistics presented in Table 1, we can observe in Graph 1 that such expected decline, which appears in the number of errors committed by the participants, seems to be more substantial within the explicit group $(-2.29)$, which received explicit feedback, as compared to the implicit group (-0.9), which received implicit feedback.

GRAPH 1-Implicit (CON) and explicit (EXP) accuracy scores pre and post intervention

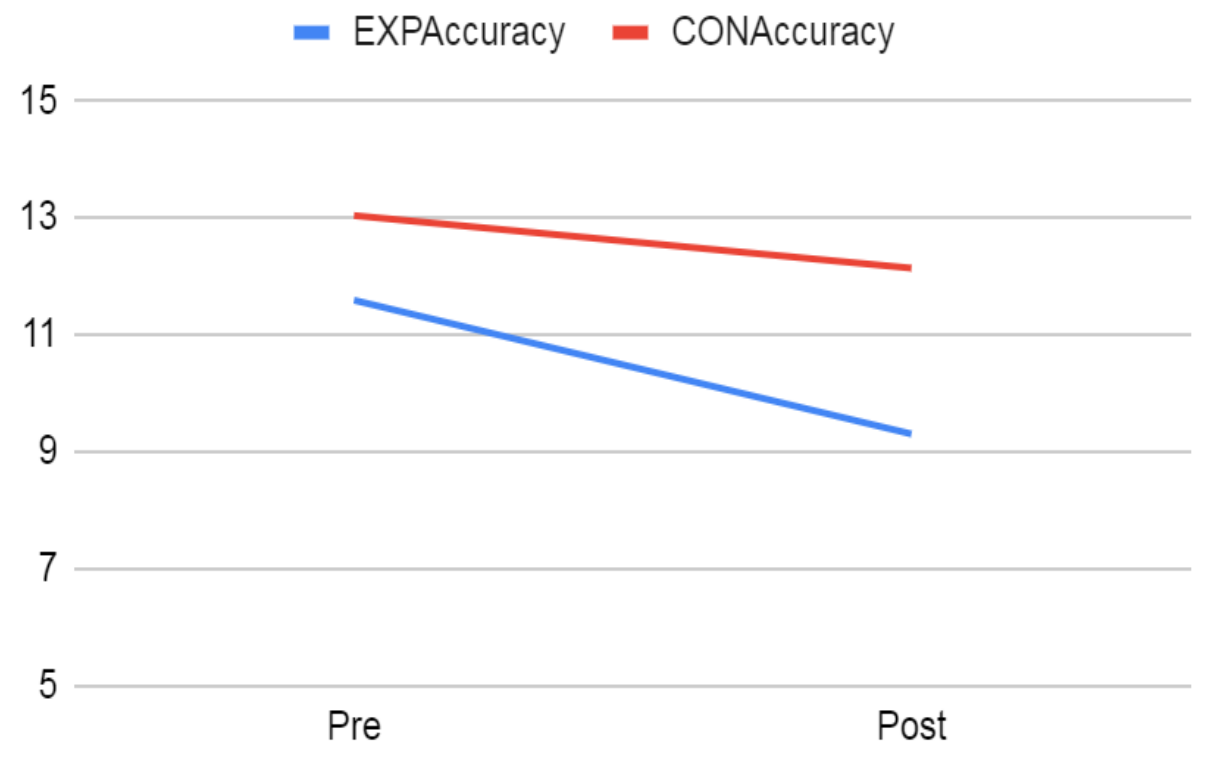

At first glance, the means reported in Table 1 showed the expected direction, suggesting that the explicit feedback group might have benefitted greater from the intervention. However, when we run the within-groups paired-samples T-tests we can observe that the results of none of the groups reached statistical significance (explicit group $p=0.07$ and implicit group $p$ $=0.338$ ), which does not allow us to support the explicit feedback advantage observed by looking at the means and effect sizes alone.

To delve a bit deeper into the tendency observed in the descriptive statistics in favor of the explicit group, we ran an additional between-groups T-test, this time comparing only the post-tests means of the two groups. The results (displayed in Graph 2) indicated that this difference was indeed significant $(p=.009)$, attesting an advantage towards the explicit group - which corroborates our claim that learners may benefit more from explicit grammar-based feedback than from content-based feedback. In addition, the fact that the between-groups difference did not reach significance in the pre-test allows us to further support our claim that the differences in the post-test were due to the intervention per se, and not to pre-existing differences between the two groups. 
Volume 15 - Número 2 - ago/dez de 2020

GRAPH 2-Implicit (CON) and explicit (EXP) post-test accuracy scores

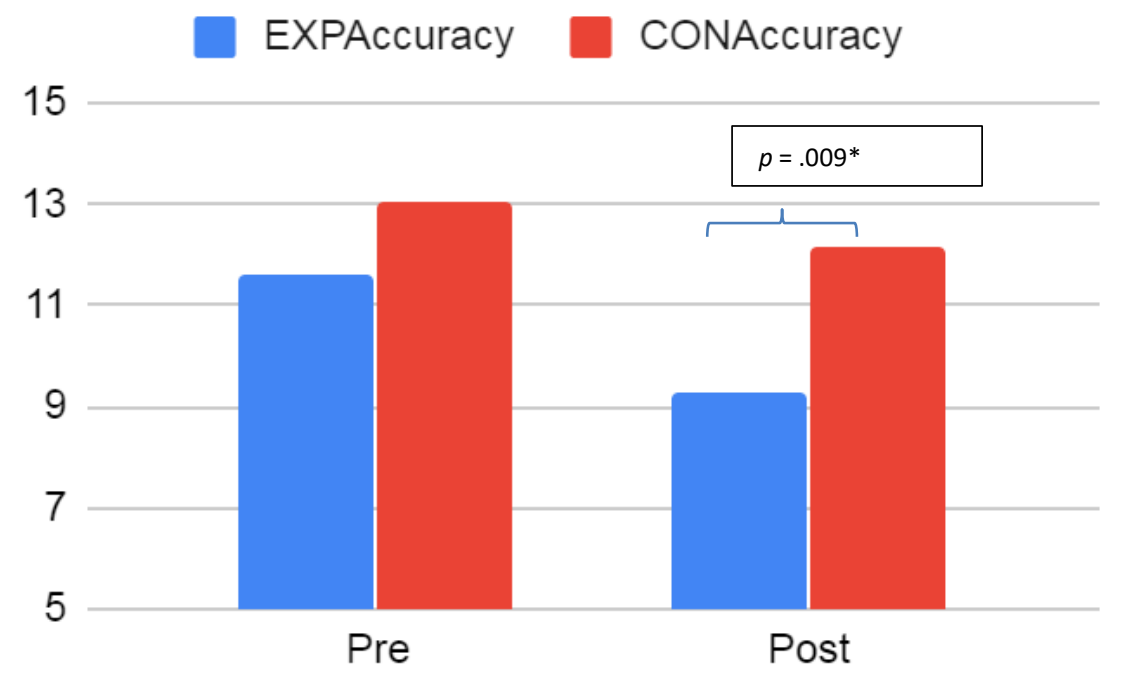

Taken together, these results seem to support Ellis (1994) and Ellis, Loewen and Erlam's (2006) claims that explicit feedback is more effective on promoting learning, because, by receiving it, students are more prompt to understand what the problem is, which helps them to internalize the rule and, hence, to avoid similar mistakes in the future.

After analyzing grammatical accuracy results, we applied the same procedure to the weighted lexical density scores (displayed in Table 2 and Graph 3), and we observed that, contrary to our predictions, there was a small increase in the weighted lexical density scores of the implicit group (IMPpostWLD: 71.1800, IMPpreWLD: 70.6368, increase of 0.5432). In relation to the explicit group, we found a small decrease in this variable (EXPpostWLD: 69.4038, EXPpreWLD: 70.5138, decrease of -1.11), and a very small effect size for both cases (Cohen's $d=0,16$ and 0,08).

TABLE 2 - Descriptive Statistics of implicit and explicit weighted lexical density scores

\begin{tabular}{|l|l|l|l|l|l|l|}
\hline & N & Minimum & Maximum & Mean & $\begin{array}{l}\text { Std. } \\
\text { Deviation }\end{array}$ & $\begin{array}{l}\text { Cohen's } \\
d\end{array}$ \\
\hline EXPpreWLD & 29 & 59,25 & 82,14 & $\mathbf{7 0 , 5 1 3 8}$ & 6,50647 & 0,16 \\
EXPpostWLD & 29 & 55,17 & 84,09 & $\mathbf{6 9 , 4 0 3 8}$ & 7,19534 & \\
IMPpreWLD & 25 & 55,93 & 82,69 & $\mathbf{7 0 , 6 3 6 8}$ & 6,88964 & 0,08 \\
IMPpostWLD & 25 & 57,57 & 84,31 & $\mathbf{7 1 , 1 8 0 0}$ & 6,67201 & \\
\hline
\end{tabular}


Volume 15 - Número 2 - ago/dez de 2020

GRAPH 3 - Implicit (CON) and explicit (EXP) weighted lexical density scores pre and post intervention

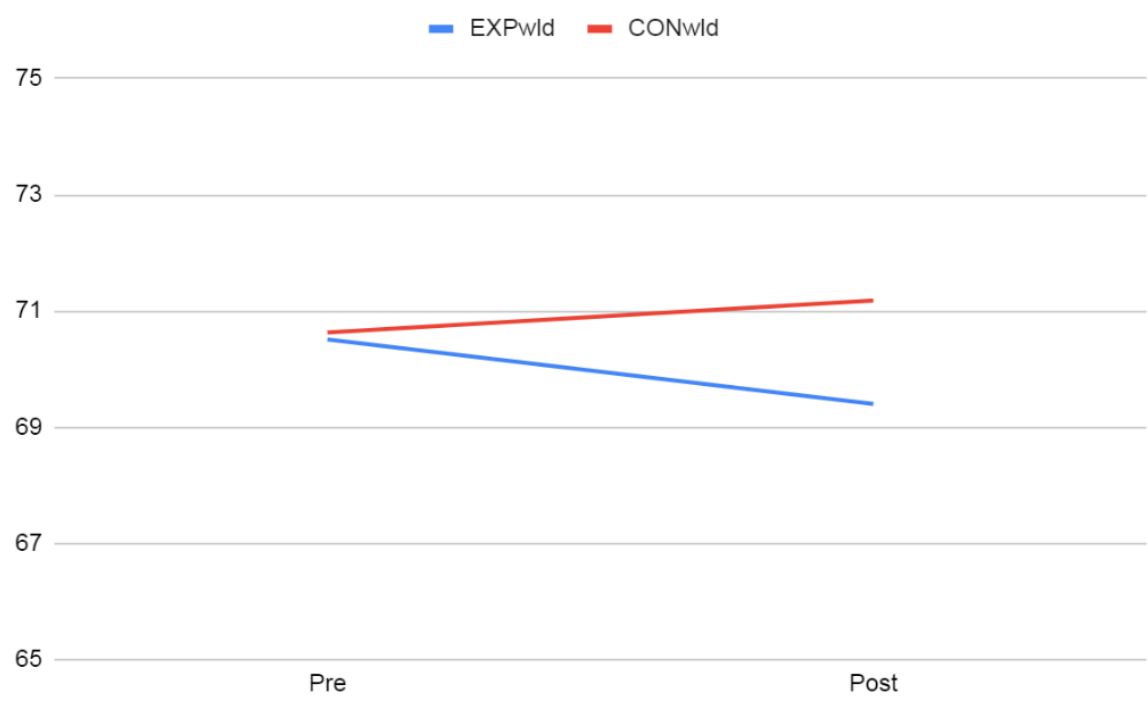

Next, we used a paired-samples T-test to compare the means of the implicit and explicit groups separately, between pre and post-tests. We can see that the results of none of the groups reached statistical significance $(p=0.539$ and $p=0.781$, for the implicit and explicit groups, respectively). The lack of statistical significance suggests that, in this particular study, the type of feedback received (explicit or implicit) did not appear to have had an impact regarding the weighted lexical density of the participants. More interestingly, the results of the explicit feedback group go in the opposite direction from expected; that is, the participants produced less lexically dense speech in the post-test. This indicates that this variable has to be investigated further in order to be able to arrive to firm conclusions on how it is impacted by the kind of feedback provided.

The last speech variable we analyzed was fluency. We compared participants' pre and post-test fluency scores (Table3 and Graph 4), and we observed that the difference between them is almost imperceptible (0.8964 in the implicit group and 0.7459 in the explicit group), although in the expected direction. Again, there was a very small effect size for both groups (Cohen's $d=0,16$ and 0,17 ).

TABLE 3 - Descriptive Statistics of implicit and explicit fluency scores

\begin{tabular}{|l|l|l|l|l|l|l|}
\hline & N & Minimum & Maximum & Mean & $\begin{array}{l}\text { Std. } \\
\text { Deviation }\end{array}$ & $\begin{array}{l}\text { Cohen's } \\
d\end{array}$ \\
\hline EXPpreFluency & 29 & 46,99 & 67,16 & $\mathbf{5 5 , 8 1 3 8}$ & 5,18055 & 0,16 \\
EXPpostFluency & 29 & 49,68 & 62,76 & $\mathbf{5 6 , 5 5 9 7}$ & 3,92984 & \\
IMPpreFluency & 25 & 40,64 & 62,81 & $\mathbf{5 4 , 8 7 1 2}$ & 5,44511 & 0,17 \\
IMPpostFluency & 25 & 42,60 & 61,73 & $\mathbf{5 5 , 7 6 7 6}$ & 4,58986 & \\
\hline
\end{tabular}


Volume 15 - Número 2 - ago/dez de 2020
GRAPH 4 - Implicit (CON) and explicit (EXP) fluency scores pre and post intervention
- EXPFluency - confluency

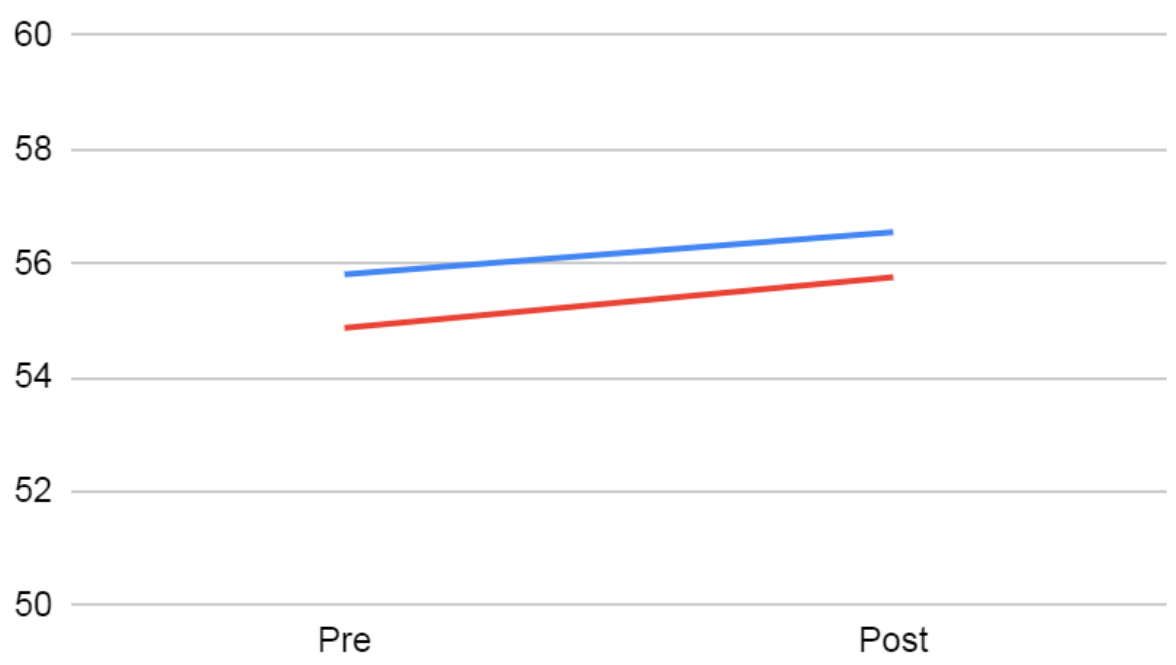

Once again, we used a T-test to compare the means of the implicit and explicit groups separately. We observed that the results of none of the groups reached statistical significance ( 0.538 and 0.565 , for the implicit and explicit groups, respectively), which again suggests that the type of feedback received did not seem to have impacted the fluency of the participants in our study, although there is a trend moving in the expected direction.

It is important to acknowledge that the development of fluency needs a longer period of time to be achieved, mainly because fluency, unlike accuracy, relies on procedural memory to a greater extent; that is, it is not directly subjected to declarative rules. In other words, by giving our students the possibility to reinforce grammatical rules, through explicit grammatical feedback, we can observe the development of students' accuracy (as we have shown earlier here) more quickly. As for fluency, since it is a variable whose development is based on more subtle and implicit processes, it takes longer to be mastered.

According to Ellis (2015), the fluency of a native speaker is unconscious and automatized. However, when it comes to a second language, it is often difficult for the learner to move from controlled to automatic process, because realizing the linguistic nuance of a new language requires a greater deal of effort from the learner. In what concerns our study, due to the fact that the grammatical correction also encompassed pronunciation, learners faced an even bigger challenge.

While in an ideal learning situation the perfect balance between all variables would be the best outcome, we know that the learner, in a communicative situation, tends to prioritize, consciously or not, certain aspects of speech, in the so-called trade-off effect (SKEHAN, 1996). This seems to have been the case in our research. By paying more attention to grammatical accuracy (as reported here), learners seem to have set aside their concern with producing more elaborate speech in terms of lexical density, or more fluent speech in terms of speech rate. In other words, by focusing on the production of grammatically correct speech, learners may have neglected the other aspects of oral production, namely lexical density and fluency. 
Volume 15 - Número 2 - ago/dez de 2020

\section{Conclusion}

The present study was based on investigating the impact of explicit grammar-based and implicit content-based feedback on participants' L2 speech production, in terms of grammatical accuracy, weighted lexical density and fluency.

Our study consisted of 54 English learners as L2, divided into an explicit feedback group and an implicit feedback group. The implicit group received implicit feedback based on the content, regarding the message itself. The explicit group received explicit feedback based on grammar, pointing out corrections in relation to the form of the message. The difference between the two groups consisted solely of the two distinct types of feedback received. Our hypothesis was that explicit feedback based on grammar, by making direct reference to grammatical inaccuracies and thus being more promptly incorporated by the learner, would be more beneficial than implicit feedback based on content.

On the one hand, our results indicate that, with regard to weighted lexical density and fluency, the different types of feedback do not seem to have positively impacted the oral development of the learners. On the other hand, the grammatical accuracy results show that both groups were benefited by the pedagogical intervention, with an advantage toward the experimental group, corroborating our hypothesis.

Our results are especially relevant when we consider that some students tend to underestimate the importance of grammatical accuracy in the development of oral production, either due to lack of encouragement by the teacher or to the overwhelming amount of pressure students feel to participate in spontaneous oral tasks. Hence, providing explicit feedback to students may help them become more aware of the benefits of a focus on form.

That said, there are some limitations that need to be addressed in relation to this study. First, our study did not have a group that carried out the tasks, but did not receive any feedback, which did not allow us to check whether only the production of the tasks would have a positive effect on the development of the learners' oral production. Second, the reduced period between the pre and the post-test may have contributed to limit our results. Third, our small number of participants (54 students) does not allow us to make firmer generalizations based on such a limited data set. Fourth, even though we were dealing with a naturalistic study - in the classroom - in order to have had more reliable results, we could, following Ellis; Loewen; Erlam (2006), have measured these two feedback conditions in the acquisition of a specific grammatical structure, for example. Therefore, it is important to emphasize that the findings of the present study should be seen as suggestive rather than conclusive.

In light of the limitations mentioned above, the following suggestions for future studies are proposed: we understand that having a third group recording the audios, but not receiving any feedback on them, would help us provide more consistent data on the importance of the feedback per se. Also, we understand that a greater number of participants and a longer period between the pre and the post test would translate into better results. Furthermore, we believe that directing the effect of types of feedback to the same linguistic aspects (instead of grammatical content, in the case of explicit feedback) and message (in the case of implicit feedback), would have helped reaching more reliable findings.

As a final note, we strongly believe that it is crucial to address speech production not only as a means of practicing the language, but as an indissoluble aspect of language learning. The way we see it, there is no better way to help students achieve proficiency in L2 than to empower them to notice and correct their mistakes, and to find the best way to avoid new ones. All in all, we hope to have contributed to encourage further research on the potential of feedback in L2 learning and teaching. 
Volume 15 - Número 2 - ago/dez de 2020

\section{References}

BERGSLEITHNER, J. Working memory capacity, noticing, and L2 speech production. 2007. Tese (doutorado em Letras)-Programa de Pós-Graduação em Letras/Inglês e Literatura Correspondente, Universidade Federal de Santa Catarina, Florianópolis.

BOTTENTUIT, J.; ALBUQUERQUE, O.; COUTINHO, C. Whatsapp e suas Aplicações na Educação: uma revisão sistemática da Literatura. Revista Educação Online, v. 10, n. 2, p.6787, 2016.

BOUHNIK, D.; DESHEN, M. WhatsApp goes to school: Mobile instant messaging between teachers and students. Journal of Information Technology Education, v.13, n. 2, p. 217-231, 2014.

COSTA, G. Mobile learning: explorando potencialidades com o uso do celular no ensinoaprendizagem de língua inglesa como língua estrangeira com alunos da escola pública. 2013. Tese (Doutorado em Letras). Departamento de Letras, Universidade Federal de Pernambuco, Recife.

DEHAENE, S. How we learn: Why brains learn better that any machine...for now. New York: Penguin Random House, 2020.

ELLIS, N. Implicit and Explicit Language Learning: Their dynamic interface and complexity. In: REBUSCHAT, P (Ed.).Implicit and explicit learning of languages. Amsterdam: John Benjamins, 2015. p. 3-23.

ELLIS, R. The study of Second Language Acquisition. Oxford: Oxford University Press, 1994.

ELLIS, R. The Differential Effects of Three Types of Task Planning on the Fluency, Complexity, and Accuracy in L2 Oral Production. Applied Linguistics, v.30, n. 4, p. 474-509, 2009.

Ellis, R.; Loewen, S.; Erlam, R. Implicit and explicit corrective feedback and the acquisition of 12 grammar. Studies in Second Language Acquisition, v. 28, n. 2, p. 339-68, 2006.

IZUMI, S.; BIGELOW, M. Does output promote noticing and second language acquisition? TESOL Quarterly, v. 34, p. 239-278, 2000.

IZUMI, S. A study of the role of awareness in foreign language behavior: aware vs. unaware learners. Studies in Second Language Acquisition, v. 22, p. 557-584, 2000.

IZUMI, S. Input Enhancement and L2 Grammatical Development: What the Research Reveals. Georgetown University, p.14-32, 2009.

LEOW, R. Attention, awareness and foreign language behavior. Language Learning, v. 47, p. 467-506, 1997.

LEOW, R. A study of the role of awareness in foreign language behavior: aware vs. unaware learners. Studies in Second Language Acquisition, v. 22, p. 557-584, 2000.

LEOW, R. What the Research Reveals. Georgetown University, p.14-32, 2009.

SKEHAN, P. Second language acquisition research and task-based research. In: WILLIS, J. WILLIS, D. (Eds.) Challenge and change in language teaching. Heinemann: Oxford, 1996. p. 17-30.

SKEHAN, P.; FOSTER, P. The influence of planning and post-task activities on accuracy and complexity in task-based learning. Thames Valley University. Working Papers in English Language Teaching, v. 3, 1996.

SCHMIDT, R. The Role of Consciousness in Second Language Learning. Applied Linguistics, v. 11, p. 129-158, 1990.

SCHMIDT, R. Consciousness and foreign language learning: a tutorial on the role of attention and awareness in learning. In: Schmidt, R. (Ed.) Attention and awareness in foreign language learning. Manoa: Second Language \& Curriculum Center, University of Hawaii at Manoa, 1995. p. 1-63. 
SCHMIDT, R. "Attention." In: Robinson, P. (Ed.), Cognition and second language instruction. Cambridge: Cambridge University Press, 2001. p. 3-32.

SCHMIDT, R. Attention, awareness, and individual differences in language learning. In: Chan, W.; CHI, S.; CIN, K. ISTANTO, J.; NAGAMI, M.; SEW, J.; Suthiwan, T.; WALKER, I. Proceedings of CLaSIC 2010, Singapore, December v. 2, n.4, p. 721-737, 2010.

SWAIN, M. The output hypothesis: just speaking and writing aren't enough. Canadian Modern Language Review, Toronto, v. 50, n. 1,p.158-64, 1993.

SWAIN, M. Three functions of output in second language learning. In: COOK, G.;SEIDLHOFER, B. (Eds), Principles and practice in the study of language. Oxford: Oxford University Press, 1995. p. 125-144.

WEISSHEIMER, J. Working memory capacity and the development of L2 speech production: an exploratory study. 2007. Tese (doutorado em Letras)-Programa de PósGraduação em Letras/Inglês e Literatura Correspondente, Universidade Federal de Santa Catarina, Florianópolis. 